\title{
Sustaining productivity of a Vertosol at Warra, Queensland, with fertilisers, no-tillage or legumes. 9. Production and nitrogen benefits from mixed grass and legume pastures in rotation with wheat
}

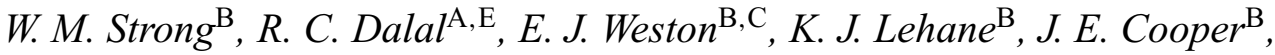 \\ A. J. King ${ }^{\mathrm{D}}$ and C. J. Holmes ${ }^{\mathrm{D}}$

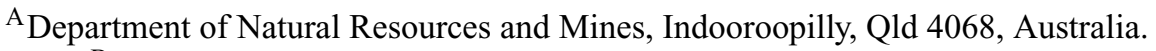 \\ ${ }^{B}$ Department of Primary Industries, Toowoomba, Qld 4350, Australia. \\ ${ }^{\mathrm{C}}$ Current address: 50 Broadwater Terrace, Redland Bay, Qld 4165, Australia. \\ ${ }^{D}$ Department of Natural Resources and Mines, Toowoomba, Qld 4350, Australia. \\ ${ }^{\mathrm{E} C}$ Corresponding author. Email: ram.dalal@nrm.qld.gov.au
}

\begin{abstract}
Reduced supplies of nitrogen $(\mathrm{N})$ in many soils of southern Queensland that were cropped exhaustively with cereals over many decades have been the focus of much research to avoid declines in profitability and sustainability of farming systems. A 45-month period of mixed grass (purple pigeon grass, Setaria incrassata Stapf; Rhodes grass, Chloris gayana Kunth.) and legume (lucerne, Medicago sativa L.; annual medics, M. scutellata L. Mill. and $M$. truncatula Gaertn.) pasture was one of several options that were compared at a fertility-depleted Vertosol at Warra, southern Queensland, to improve grain yields or increase grain protein concentration of subsequent wheat crops. Objectives of the study were to measure the productivity of a mixed grass and legume pasture grown over 45 months (cut and removed over 36 months) and its effects on yield and protein concentrations of the following wheat crops.

Pasture production (DM t/ha) and aboveground plant $\mathrm{N}$ yield $(\mathrm{kg} / \mathrm{ha}$ ) for grass, legume (including a small amount of weeds) and total components of pasture responded linearly to total rainfall over the duration of each of 3 pastures sown in 1986, 1987 and 1988. Averaged over the 3 pastures, each $100 \mathrm{~mm}$ of rainfall resulted in $0.52 \mathrm{t} / \mathrm{ha}$ of grass, $0.44 \mathrm{t} / \mathrm{ha}$ of legume and $0.97 \mathrm{t} / \mathrm{ha}$ of total pasture DM, there being little variation between the 3 pastures. Aboveground plant $\mathrm{N}$ yield of the 3 pastures ranged from 17.2 to $20.5 \mathrm{~kg} / \mathrm{ha}$ per $100 \mathrm{~mm}$ rainfall. Aboveground legume $\mathrm{N}$ in response to total rainfall was similar $(10.6-13.2 \mathrm{~kg} / \mathrm{ha} .100 \mathrm{~mm}$ rainfall) across the 3 pastures in spite of very different populations of legumes and grasses at establishment. Aboveground grass $\mathrm{N}$ yield was $5.2-7.0 \mathrm{~kg} / \mathrm{ha}$ per $100 \mathrm{~mm}$ rainfall.

In most wheat crops following pasture, wheat yields were similar to that of unfertilised wheat except in 1990 and 1994, when grain yields were significantly higher but similar to that for continuous wheat fertilised with $75 \mathrm{~kg} \mathrm{~N} / \mathrm{ha}$. In contrast, grain protein concentrations of most wheat crops following pasture responded positively, being substantially higher than unfertilised wheat but similar to that of wheat fertilised with $75 \mathrm{~kg} \mathrm{~N} / \mathrm{ha}$. Grain protein averaged over all years of assay was increased by $25-40 \%$ compared with that of unfertilised wheat.

Stored water supplies after pasture were $<134 \mathrm{~mm}$ ( $<55 \%$ of plant available water capacity); for most assay crops water storages were $67-110 \mathrm{~mm}$, an equivalent wet soil depth of only $0.3-0.45 \mathrm{~m}$. Thus, the crop assays of pasture benefits were limited by low water supply to wheat crops. Moreover, the severity of common root rot in wheat crop was not reduced by pasture-wheat rotation.
\end{abstract}

Additional keywords: annual medic, lucerne, purple pigeon grass, Rhodes grass, soil nitrogen fertility, soil nitrate, soil water.

\section{Introduction}

The cereal growing areas of southern Queensland and northern New South Wales have relied largely on native soil nitrogen $(\mathrm{N})$ fertility, which has been declining since cereal cropping began almost 100 years ago (Dalal and
Mayer 1986a; Hallsworth et al. 1954), resulting in static or declining cereal yields and grain protein concentrations (Dalal et al. 1991). To continue to crop these lands profitably and sustainably requires $\mathrm{N}$ supply to be supplemented by either the application of $\mathrm{N}$ fertiliser (Holford and Doyle 1992; 
Strong et al. 1996b) or inclusion of legumes in rotation with cropping (Armstrong et al. 1999a, 1999b; Dalal et al. 2004a, 2004b; Holford 1980; Holford and Crocker 1997; Holford et al. 1998; Hossain et al. 1996b; Littler 1984; Weston et al. 2002; Whitehouse and Littler 1984).

In the cereal growing areas of northern New South Wales and southern Queensland, it has been shown that periods of legume pasture even as short as 2 years of annual medics or lucerne, significantly increases soil mineral $\mathrm{N}$ available for subsequent cropping as well as yields and protein concentrations of subsequent cereal grain (Dalal et al. 1991, 2004a, 2004b; Holford et al. 1998; Hossain et al. 1996a, 1996b; Weston et al. 2002). Higher than expected pasture production with a mixture of grasses and legumes and the summer-dominant rainfall that favours grasses prompted the question as to whether mixed pastures might impart similar benefits as pure legume swards while improving the quantity or quality of forage for animals while reducing the risk of bloating.

In pure legume swards, $\mathrm{N}$ benefit to a following cereal crop depends on productivity during the preceding legume phase. Nitrogen fixed by lucerne for example appears closely associated with the total amount of dry matter produced; on average, $20-25 \mathrm{~kg} \mathrm{~N}$ is fixed for each tonne of legume dry matter produced (Peoples and Baldock 2001). At this site, dry matter production and $\mathrm{N}$ yields of lucerne were closely correlated with the total (October-September) growing season rainfall as well as March-September rainfall (Dalal et al. 2004a). Each $100 \mathrm{~mm}$ of total growing season rainfall resulted in $0.97 \mathrm{t} / \mathrm{ha}$ of dry matter and $26 \mathrm{~kg} / \mathrm{ha}$ of aboveground N. Response of lucerne to rainfall in autumn and winter (March-September) was $1.26 \mathrm{t} / \mathrm{ha}$ for dry matter and $36 \mathrm{~kg} / \mathrm{ha}$ for aboveground $\mathrm{N}$. These values were $10 \%$ less than that for autumn and winter-growing annual medics for the same period. Comparative values for legumes growing in mixed grass and legume pastures are of interest in establishing the potential benefit to $\mathrm{N}$ fertility management for subsequent cereal cropping.

The objectives of this study, therefore, are to measure the productivity of mixed grass and legume pasture grown over 45 months (grazed or cut and removed over 36 months) and its effects on yields and protein concentrations of the following wheat crops. We report in this paper production of the 3 phases of mixed grass and legume pastures, soil $\mathrm{N}$ concentration and the effects on the grain production and protein concentrations of the subsequent wheat crops.

\section{Materials and methods}

Site details

The field experiments were conducted at Warra $\left(26^{\circ} 47^{\prime} \mathrm{S}, 150^{\circ} 53^{\prime} \mathrm{E}\right)$ in southern Queensland on a soil that had been cultivated for cereal cropping since 1935. The soil is a Vertosol (Typic Chromustert) that has lost $70 \%$ of organic $\mathrm{C}$ (from 2.23 to $0.68 \%$ ) and total $\mathrm{N}$ (from 0.203 to $0.06 \%$ ) from the $0-0.1 \mathrm{~m}$ layer after 50 years (Dalal and Mayer
$1986 b, 1986 c$ ). Detailed description of the soil, and mean monthly maximum and minimum temperatures, and mean monthly rainfall, and growing season rainfall at the field site (1987-98) are described in earlier papers of this series (Dalal et al. 2004a; Weston et al. 2002). Briefly, the soil contains 56, 17 and $27 \%$ clay, silt and sand, respectively. It is alkaline at the surface ( $\mathrm{pH}$ of 8.6 in $1: 5$ soil : water mixture) trending to strongly acidic ( $\mathrm{pH} 4.9)$ at $1.2 \mathrm{~m}$ depth. Annual rainfall varied from $396 \mathrm{~mm}$ in 1986 , to $759 \mathrm{~mm}$ in 1988 . Over the decade commencing in 1986, 45 month periods of pasture would have received as little as $1950 \mathrm{~mm}$ of rainfall if sown in 1990, or as much as $2450 \mathrm{~mm}$ if sown in 1987 or 1993.

\section{Pasture establishment}

Details of the experiment have been described previously by Dalal et al. (1995). Briefly, a mix of lucerne (Medicago sativa L. cv. Trifecta) at $1.5 \mathrm{~kg} / \mathrm{ha}$, annual medics (M. scutellata L. Mill. cv. Sava and Kelson and M. truncatula Gaertn. cv. Jemalong) at $2 \mathrm{~kg} / \mathrm{ha}$, and purple pigeon grass, Setaria incrassata Stapf cv. Inverell at $2 \mathrm{~kg} / \mathrm{ha}$, and Rhodes grass, Chloris gayana Kunth cv. Katambora, at $2 \mathrm{~kg} / \mathrm{ha}$, were established in January 1986, 1987 and 1988 in a randomised block design with 4 replications (plot size, 6.75 by $25 \mathrm{~m}$ ) in an experiment that compared a range of options to increase the $\mathrm{N}$ supply to subsequent wheat crops. Each pasture sowing time treatment was established with 2 replicates in an area adjacent to the randomised block where they were grazed by sheep commencing 1 year after pasture establishment.

We attempted to reduce the influence of rainfall variability across seasons by sowing the same mix of grass and legume pasture species in 3 successive seasons, 1986, 1987 and 1988, which were removed by tillage (blade plough) in 1989, 1990 and 1991, respectively, henceforth refereed to as GL86, GL87, and GL88, respectively. Hence the 3 pastures were representative of different sequences of growing conditions.

\section{Pasture management}

In the randomised block, pasture production was measured by manually harvesting five 1 by $1 \mathrm{~m}$ quadrats to $25 \mathrm{~mm}$ height, and the remaining plants by forage harvesting to a height of $0.1 \mathrm{~m}$ at 3-monthly intervals in December, March, June and September. All cut and forage harvested material was removed from the plots. Weeds contributed $<1 \%$ of the total pasture biomass. In adjacent grazed plots, pastures were grazed by sheep to about $0.1 \mathrm{~m}$ height during the 4 weeks prior to forage harvest. In grazed plots, pasture was harvested ( 5 quadrats each 1 by $1 \mathrm{~m}$ ) from within animal exclosures at 3-monthly intervals to estimate dry matter (DM) yield, pasture composition and aboveground $\mathrm{N}$ in grasses, legumes and weeds. Plant material was dried at $75^{\circ} \mathrm{C}$, weighed and ground to pass through a $1-\mathrm{mm}$ sieve and $\% \mathrm{~N}$ determined by Kjeldahl analysis (Crooke and Simpson 1971).

Pastures were terminated in early October by blade ploughing, about $0.10-0.15 \mathrm{~m}$ deep, to coincide with maturity of annual legumes and cereal crops and to provide similar opportunity for soil water to recharge as for continuous cropping during the fallow period. Weeds were controlled during the fallow by tillage to about $0.1 \mathrm{~m}$ depth ( 2 or 3 events) as for continuous cropping.

\section{Crop and soil management}

Wheat was sown at a $0.25-\mathrm{m}$ spacing at a rate of $40 \mathrm{~kg} / \mathrm{ha}$ in May or June or $50 \mathrm{~kg} / \mathrm{ha}$ when sown in July 1990 and 1993. Little weed control was required during wheat cropping. Wheat crop received a basal rate of $10 \mathrm{~kg} / \mathrm{ha}$ of phosphorus as superphosphate, fortified with copper and zinc annually at sowing; pastures were top-dressed with the same fertiliser at the same rate annually.

Harvest index was calculated from grain and straw yield estimates by harvesting 1-m lengths of 2 adjacent plant rows just before harvest, drying at $75^{\circ} \mathrm{C}$ and separating and measuring the mass of grain and straw. Wheat grain yields were measured from machine harvesting $1.75 \mathrm{~m}$ by about $23 \mathrm{~m}$ of the central area of each plot. Grain yields were adjusted to $12 \%$ moisture content and grain and straw $\% \mathrm{~N}$ determined by 
Kjeldahl digestion followed by automated ammonium analysis (Crooke and Simpson 1971).

Soil sampling and analysis

Soil was sampled to a depth of $1.5 \mathrm{~m}$ for soil water and nitrate contents using a 50-mm diameter tube hydraulic sampler in May (presowing) and November (after harvest) each year. Two soil cores taken from each plot were bulked by $0.1-\mathrm{m}$ layers to a depth of $0.3 \mathrm{~m}$ and by $0.3-\mathrm{m}$ layers below $0.3 \mathrm{~m}$ depth. Soil samples were stored in airtight bags at $4{ }^{\circ} \mathrm{C}$ until analysis. Soil moisture content was determined gravimetrically by drying soil samples at $105^{\circ} \mathrm{C}$ for $48 \mathrm{~h}$ and converted to volumetric soil moisture content (mm/layer) using a bulk density adjusted for the soil moisture content for the layer (Strong et al. 1996a). For nitrate analysis, soil was dried at $35^{\circ} \mathrm{C}$ under draught, and ground to $<2 \mathrm{~mm}$ for colorimetric determination of nitrate (Best 1976) after extraction of $10 \mathrm{~g}$ of soil in $100 \mathrm{~mL}$ of $2 \mathrm{~mol} / \mathrm{L} \mathrm{KCl}$.

\section{Root diseases}

The occurrence of root diseases, common root rot (Bipolaris sorokiniana), crown rot (Fusarium graminearum) and root lesion nematodes (Pratelenchus thornei) were assessed following the pasture phase. The assessment methodology for these soil borne root diseases was reported earlier (Dalal et al. 2004a). Briefly, the incidence and severity of common root rot and crown rot of wheat were assessed from randomly collected 50 wheat plants with their roots from each plot at anthesis. The subcrown internode of each plant was examined for the extent of lesions due to common root rot (Wildermuth et al. 1992). Incidence of crown rot was assessed by examining the first internode of tillers for honey brown to dark brown discoloration. Root lesion nematode effects were assessed from root lesion nematodes present in soil in May in 1988. None were found and hence no further assessments were made in subsequent years.

\section{Results}

Pasture composition

Pasture GL86 resulted in a similar numbers of Rhodes and purple pigeon grass and legume plants, mostly lucerne (5-8 lucerne plants $/ \mathrm{m}^{2}$ ) (Fig. 1a). Pasture GL87 resulted in establishment of fewer grasses but the population increased during subsequent years of the pasture (Fig. 1b). The high lucerne population declined during the pasture phase to about one half of that established but remained $>10$ lucerne plants $/ \mathrm{m}^{2}$. Pasture GL88 resulted in a grass dominant mix of mainly Rhodes grass. The modest population of legumes (5-8 lucerne plants $/ \mathrm{m}^{2}$ ) that was established decreased only during the last year of the pasture (Fig. 1c).

\section{Pasture production}

Despite different populations of grass and legume plants established in the 3 pasture sowing times, total dry matter production of grasses, legumes and grasses + legumes was similar and was closely related to total rainfall (Fig. 2). Response of grasses + legumes to $100 \mathrm{~mm}$ of total rainfall ranged from 0.93 to $1.07 \mathrm{t} / \mathrm{ha}$ across the 3 pastures, the relationship, $y=9.682 x+1330.2\left(R^{2}=0.9\right)$, describing pasture response $(\mathrm{kg} / \mathrm{ha}, y)$ to incident rainfall $(\mathrm{mm}, x)$, or $0.97 \mathrm{t} / \mathrm{ha} .100 \mathrm{~mm}$. Grasses responded more $(0.51-0.69 \mathrm{t} / \mathrm{ha} .100 \mathrm{~mm})$ to incident rainfall than legumes $(0.37-0.49 \mathrm{t} / \mathrm{ha} .100 \mathrm{~mm})$ in each mixed pasture (Table 1$)$. In spite of the different populations of legume plants

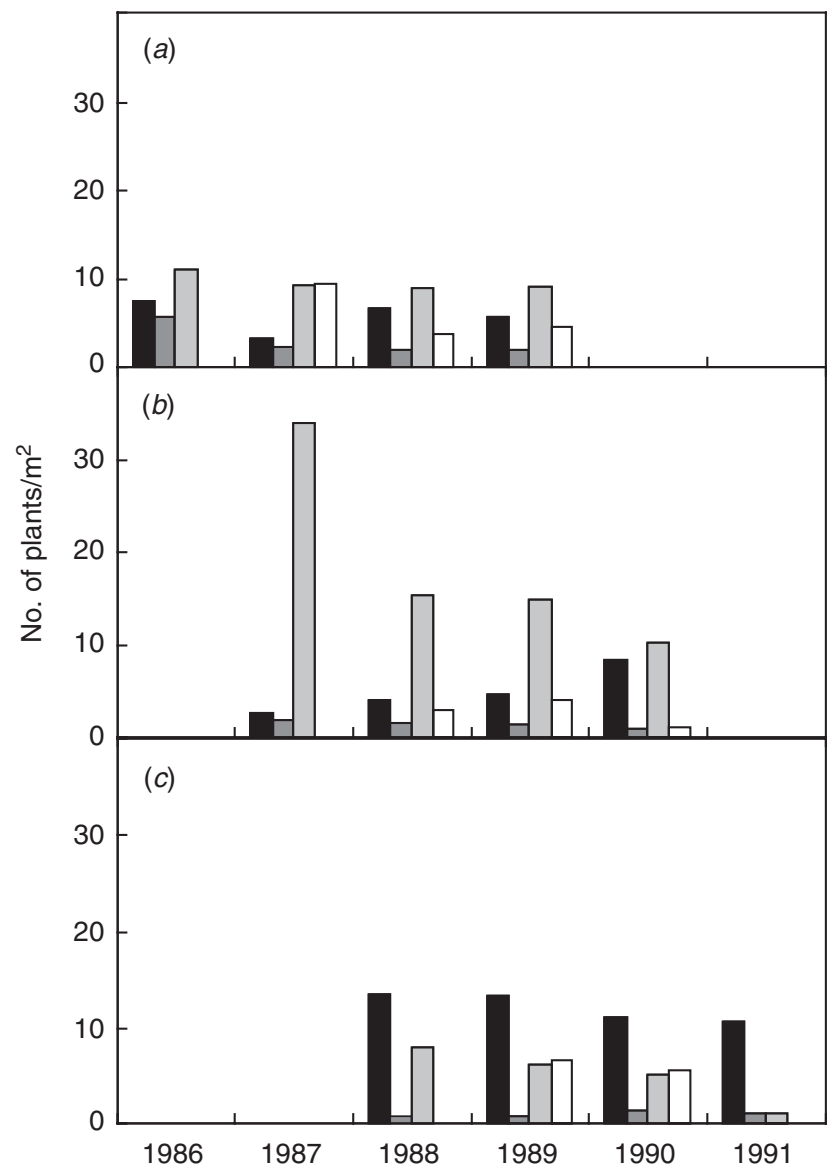

Fig. 1. Annual composition of mixed grass and legume pastures sown in 1986, 1987 and 1988 and terminated in 1989, 1990, 1991 [(a) GL86; (b) GL87; (c) GL88], respectively, showing populations of Rhodes grass (black bars), purple pigeon grass (dark grey bars), lucerne (light grey bars) and medics (white bars).

established in the 3 pastures, there was closer association between total rainfall and legume production $\left(R^{2}=0.94\right)$ across the 3 pastures, suggesting that incident rainfall rather than established plant numbers had the greater influence on legume production.

For each mixed pasture, production was generally similar where pasture was grazed compared with the cut and removed management in the randomised block experiment. Two exceptions to this general finding were evident during the January-March quarters of 1988 and 1989 when grass production for grazed pasture (data not shown) was nearly twice that of pasture that was cut and removed. Nutrient recycling from dung and urine in grazed pasture may have promoted increased growth, particularly of N-starved grasses. Heavy and frequent rainfall during these 2 summer periods (227 mm over 21 days in 1988 and $165 \mathrm{~mm}$ over 25 days in 1989), could have contributed to increased nutrient and pasture growth. Because of the low frequency of wet summers during this experiment, results presented 


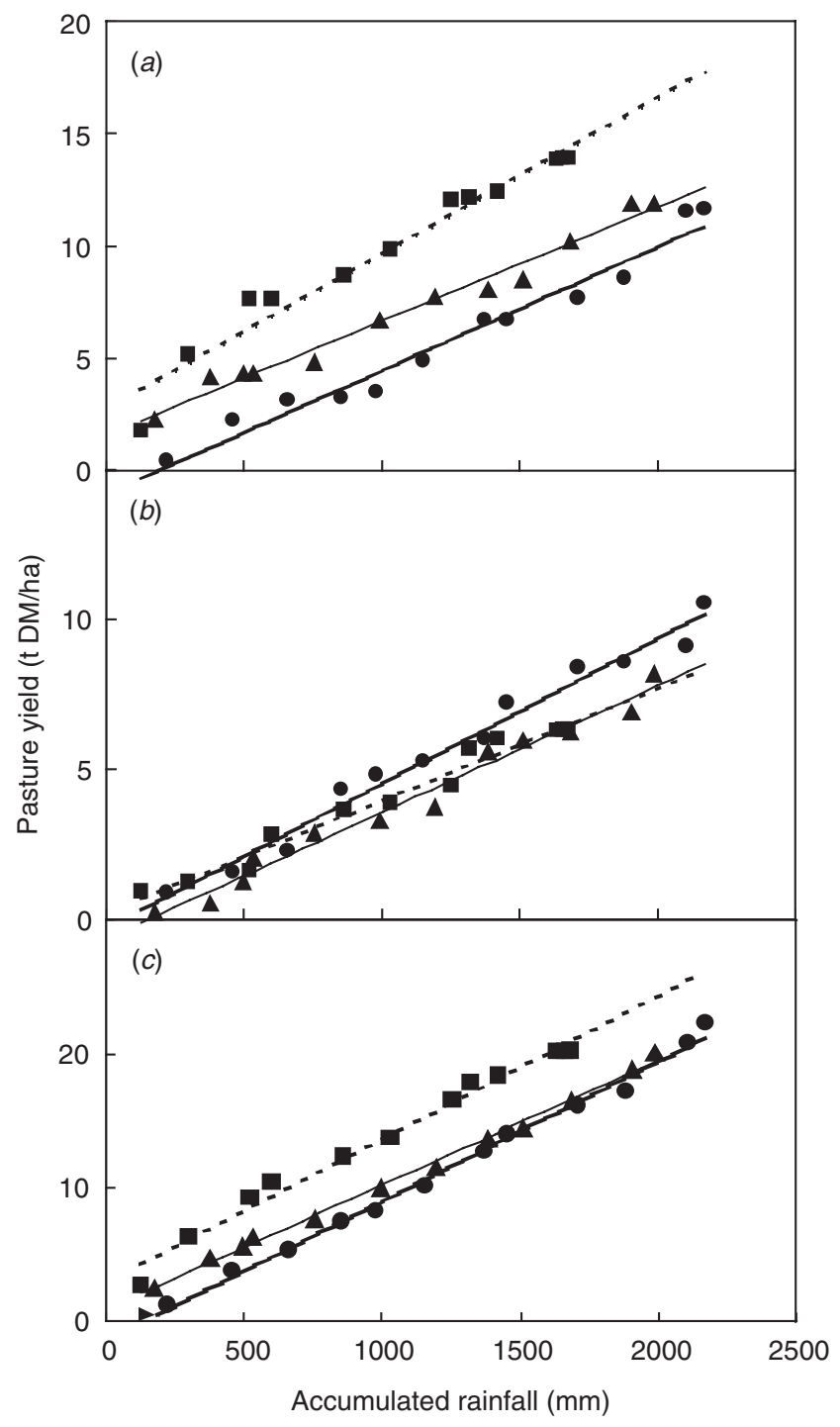

Fig. 2. Cumulative dry matter $(\mathrm{DM})$ response $(\mathrm{kg} / \mathrm{ha})$ to incident rainfall for $(a)$ grass, $(b)$ legume and $(c)$ total grass and legume pasture components for 3 pastures each of 45-months duration. Separate response relationships are shown for each pasture: GL86 ( $\mathbf{v})$, GL87 (•) and GL88 (ם).

and discussed in following sections are for cut and removed pastures only.

Highest annual pasture production (grass + legume) for GL86 and GL87 pastures occurred in 1988, and for GL88 in 1989 (Fig. 3), due largely to the high production in the January-March period of 1988 and 1989. High annual pasture productions in 1988 and 1989 were attributable largely to high grass production, about $4 \mathrm{t} / \mathrm{ha}$ for GL86 and GL87 pastures and $7 \mathrm{t} / \mathrm{ha}$ for the GL88 pasture.

\section{Aboveground pasture $N$}

Nitrogen yield $(\mathrm{kg} / \mathrm{ha})$ of mixed pastures in response to incident rainfall was similar across the 3 pastures (Fig. 4), $17.2-20.5 \mathrm{~kg} / \mathrm{ha} .100 \mathrm{~mm}$ rainfall (Table 2). Legume $\mathrm{N}$ yields
Table 1. Response to incident rainfall of aboveground dry matter (DM) ( $t / h a)$ for grass, legume and total components of mixed grass and legume pastures sown in 1986 (GL86), 1987 (GL87) and 1988 (GL88)

All $R^{2}$ values were $>0.90, P<0.05$

\begin{tabular}{|c|c|c|}
\hline Pasture & $\begin{array}{c}\text { Linear response equation } \\
\text { describing DM } \\
(\mathrm{kg} / \mathrm{ha} . \mathrm{mm})\end{array}$ & $\begin{array}{l}\text { Response to } 100 \mathrm{~mm} \\
\text { of incident rainfall } \\
(\mathrm{t} / \mathrm{ha} .100 \mathrm{~mm})\end{array}$ \\
\hline \multicolumn{3}{|l|}{ Grass + legume } \\
\hline GL86 & $y=9.309 x+911.1$ & $0.931 \pm 0.019$ \\
\hline GL87 & $y=10.448 x-1448.6$ & $1.045 \pm 0.027$ \\
\hline GL88 & $y=10.691 x+2927.8$ & $1.069 \pm 0.042$ \\
\hline All pastures & - & $0.968 \pm 0.060$ \\
\hline \multicolumn{3}{|l|}{ Grass } \\
\hline GL86 & $y=5.076 x+1586.1$ & $0.508 \pm 0.023$ \\
\hline GL87 & $y=5.508 x-1056.9$ & $0.551 \pm 0.033$ \\
\hline GL88 & $y=6.939 x+2718.6$ & $0.694 \pm 0.044$ \\
\hline All pastures & - & $0.521 \pm 0.067$ \\
\hline \multicolumn{3}{|l|}{ Legume } \\
\hline GL86 & $y=4.226 x-669.6$ & $0.423 \pm 0.020$ \\
\hline GL87 & $y=4.847 x-332.2$ & $0.485 \pm 0.022$ \\
\hline GL88 & $y=3.740 x+208.8$ & $0.374 \pm 0.020$ \\
\hline All pastures & - & $0.443 \pm 0.019$ \\
\hline
\end{tabular}

(10.6-13.2 kg/ha. $100 \mathrm{~mm}$ rainfall) were about twice the grass $\mathrm{N}$ yields $(5.2-7.0 \mathrm{~kg} / \mathrm{ha} .100 \mathrm{~mm}$ rainfall). Of the 3 pastures, highest $\mathrm{N}$ yield was obtained for the GL87, where the greatest amount of $\mathrm{N}$ was also contributed by legumes. Nitrogen yields for each $100 \mathrm{~mm}$ of incident rainfall from GL86 and GL88 were similar (Table 2).

As for pasture production, annual yield of aboveground pasture $\mathrm{N}$ (grasses + legumes) also reached a peak in 1989 (Fig. 5). Total aboveground $\mathrm{N}$ yield of grass for the duration of pasture was similar $(118-141 \mathrm{~kg} / \mathrm{ha})$ for each of the 3 pastures. Annual yield of aboveground plant $\mathrm{N}(\mathrm{kg} / \mathrm{ha})$ for legumes usually exceeded that for grasses for the duration of each pasture. Aboveground $\mathrm{N}$ yield of legumes over the duration of pasture was highest $(307 \mathrm{~kg} / \mathrm{ha})$ for GL87 and lowest $(161 \mathrm{~kg} / \mathrm{ha})$ for GL88, with that for GL86 $(253 \mathrm{~kg} / \mathrm{ha})$ intermediate. Total aboveground $\mathrm{N}$ yield of pasture (grass + legume) ranged from $297 \mathrm{~kg} / \mathrm{ha}$ (GL88) to $451 \mathrm{~kg} / \mathrm{ha}$ (GL87); GL86 was intermediate $(371 \mathrm{~kg} / \mathrm{ha})$.

\section{Soil nitrate nitrogen}

Nitrate nitrogen in the soil profile $(0-1.2 \mathrm{~m}$ depth) before wheat sowing in May following the termination of the pasture remained significantly higher than the continuous wheat treatment after GL86 from 1990 to 1994, GL87 from 1992 until the end of the wheat crop assay (1995), and GL88 for 1993 only (Table 3). For these years, nitrate $\mathrm{N}$ values were generally similar to those from the fertiliser application of $75 \mathrm{~kg} \mathrm{~N} / \mathrm{ha}$ to each wheat crop. However, GL87, the 


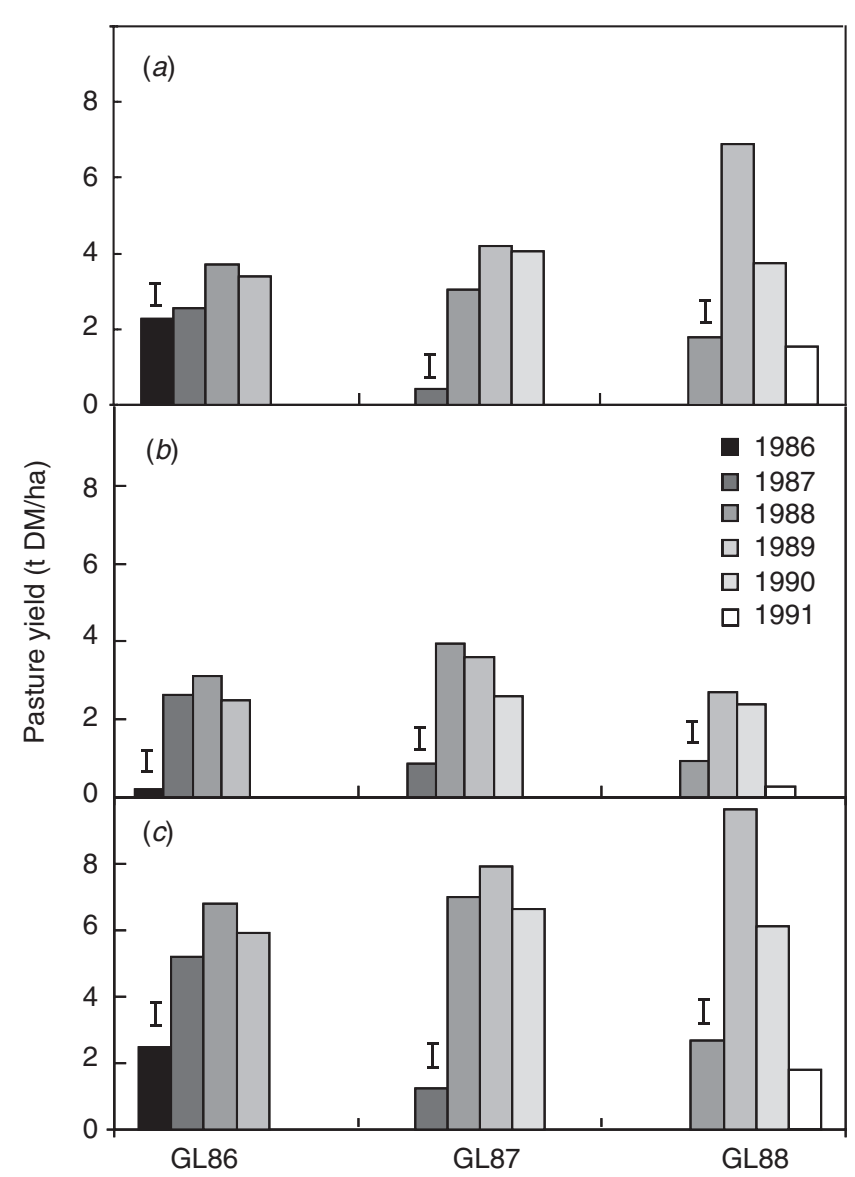

Fig. 3. Annual production ( $\mathrm{kg} / \mathrm{ha})$ of $(a)$ grass, $(b)$ legume, and $(c)$ total grass and legume pasture components during 3 mixed pastures each of 45-months duration. GL86, GL87 and GL88 are shown separately.

lucerne dominant pasture had higher nitrate $\mathrm{N}$ levels than the $75 \mathrm{~kg} \mathrm{~N} /$ ha.crop treatment in 1992 and 1993.

\section{Wheat grain yields and grain protein concentrations}

In most wheat crops following each pasture, wheat yields were similar to that of unfertilised wheat. Only in 1990 and 1994 was grain yield increased following the pasture phase (Fig. 6) and were similar to wheat fertilised with $75 \mathrm{~kg} \mathrm{~N} / \mathrm{ha}$. Moreover, wheat grain yields were lower than unfertilised wheat in 1995 following all 3 pastures (Fig. 6). In contrast, grain protein concentrations were increased substantially following each pasture, remaining higher than unfertilised wheat until termination of the crop assay (Fig. 7). Most wheat crops after GL86 or GL87 pastures produced grain of a protein concentration similar to wheat fertilised with $75 \mathrm{~kg} \mathrm{~N} / \mathrm{ha}$, but above that of unfertilised wheat. Grain protein following GL86 and GL87 was 38-40\% greater than unfertilised wheat but grain protein increased only by $25 \%$ following GL 88 . Wheat grain protein concentrations following GL86 and GL87 generally attained Prime Hard grade (13\%). Wheat grain screenings were generally $<6 \%$.

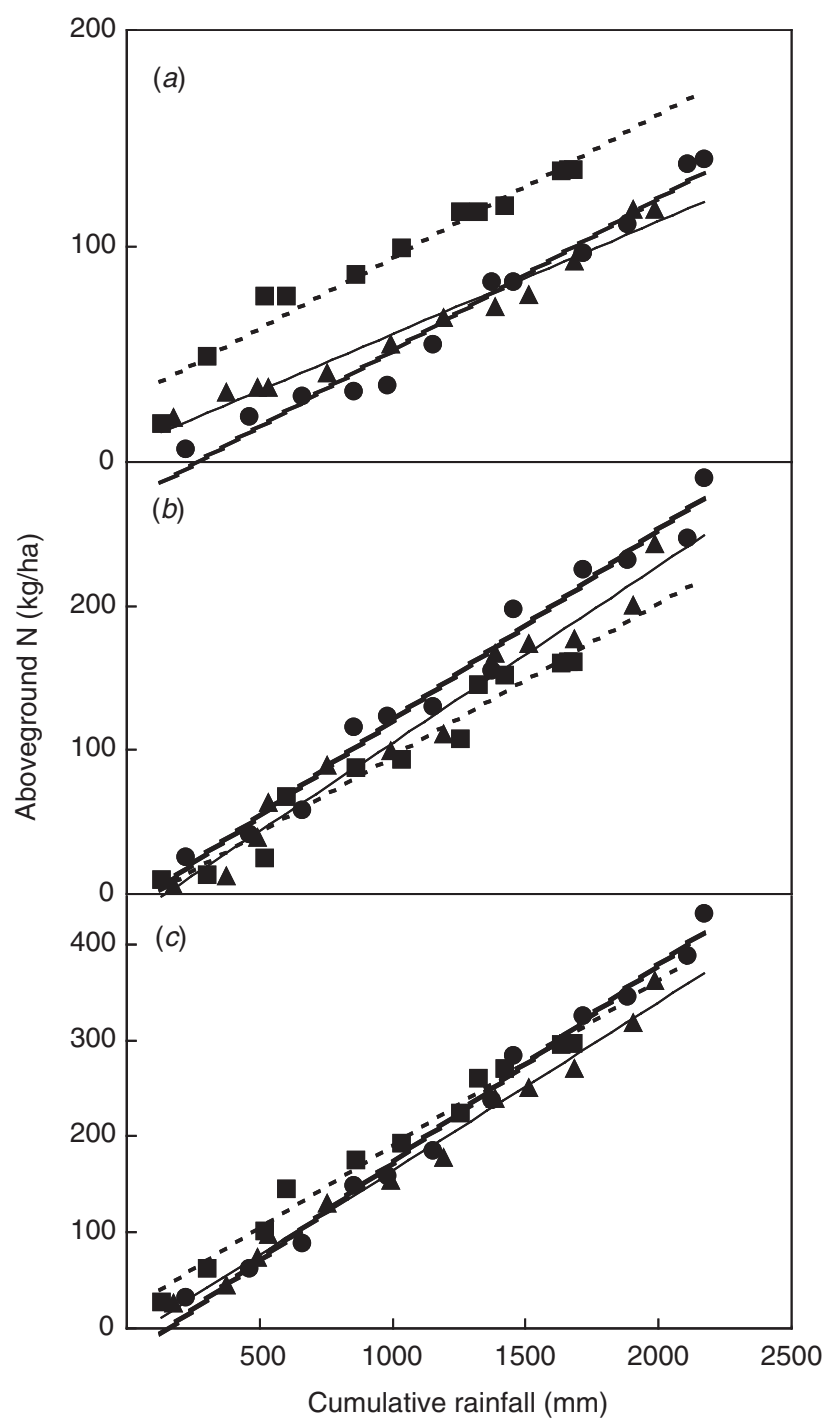

Fig. 4. Cumulative response in aboveground plant $\mathrm{N}(\mathrm{kg} / \mathrm{ha})$ to incident rainfall for ( $a$ ) grass, $(b)$ legume, and (c) total grass and legume pasture components for 3 pastures each of 45 months duration. Separate response relationships are shown for each pasture: GL86 ( $)$, GL87 (•

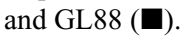

\section{Wheat grain and stubble nitrogen yield}

Wheat grain and stubble $\mathrm{N}$ yields following pasture were higher than the continuous wheat in 1990, 1993 and 1994 following all 3 pastures (Table 4), thus, showing that wheat crop $\mathrm{N}$ assay was more sensitive than that assessed from soil nitrate $\mathrm{N}$ levels at wheat sowing (Table 3). In general, wheat grain and stubble $\mathrm{N}$ yields following pastures were similar to those from $75 \mathrm{~kg} \mathrm{~N} / \mathrm{ha}$.crop application of fertiliser.

\section{Soil water}

At termination of GL86 and GL87, soil water supply was similar to that of a wheat crop fertilised with $75 \mathrm{~kg} \mathrm{~N} / \mathrm{ha}$, but a substantial soil water deficit was evident at termination 
Table 2. Response to incident rainfall of plant nitrogen $(\mathrm{kg} / \mathrm{ha})$ for grass, legume and total components of mixed grass and legume pastures sown in 1986 (GL86), 1987 (GL87) and 1988 (GL88)

All $R^{2}$ values were $>0.90, P<0.05$

\begin{tabular}{lcc}
\hline Pasture & $\begin{array}{c}\text { Linear response equation } \\
\text { describing aboveground } \mathrm{N} \\
(\mathrm{kg} / \mathrm{ha} . \mathrm{mm})\end{array}$ & $\begin{array}{r}\text { Response to } 100 \mathrm{~mm} \\
\text { of incident rainfall } \\
(\mathrm{kg} / \mathrm{ha} .100 \mathrm{~mm})\end{array}$ \\
\hline Grass + legume & $y=0.1753 x-11.032$ & $17.53 \pm 0.66$ \\
$\quad$ GL86 & $y=0.205 x-32.28$ & $20.5 \pm 0.68$ \\
GL87 & $y=0.1722 x+17.767$ & $17.76 \pm 0.66$ \\
GL88 & - & $18.52 \pm 0.54$ \\
All pastures & & \\
Grass & $y=0.0523 x+6.915$ & $5.23 \pm 0.30$ \\
GL86 & $y=0.0705 x-18.713$ & $7.05 \pm 0.38$ \\
GL87 & $y=0.0660 x+28.623$ & $6.60 \pm 0.47$ \\
GL88 & - & $5.91 \pm 0.59$ \\
All pastures & & \\
Legume & $y=0.1228 x-17.784$ & $12.28 \pm 0.68$ \\
GL86 & $y=0.1324 x-12.197$ & $13.24 \pm 0.67$ \\
GL87 & $y=0.106 x-10.86$ & $10.6 \pm 0.66$ \\
GL88 & - & $12.49 \pm 0.52$ \\
All pastures & & \\
\hline
\end{tabular}

of the GL88 (Fig. 8). The exceptionally dry year when this pasture was terminated and the high density of grasses in the pasture were probable causes for the large soil water deficit. Plant available water in soil was generally higher in the continuous wheat without fertiliser $\mathrm{N}$ application than the pasture treatments, possibly owing to lower water use limited by $\mathrm{N}$ supply.

In May when winter cereals are usually sown, soil water supplies after the 3 pastures were similar to that of wheat fertilised with $75 \mathrm{~kg} \mathrm{~N} / \mathrm{ha}$, but slightly lower than wheat grown without $\mathrm{N}$ fertilisation. Water deficit, which was evident immediately after the GL88, had disappeared by May, but a modest water deficit was present in May 1995 (Fig. 9). Soil water storages by May in years of assay following pasture were generally below that desired to grow good winter cereal crops in low rainfall winter seasons of northern Australia. Except for the 1992 crop, which followed 2 years of fallow,

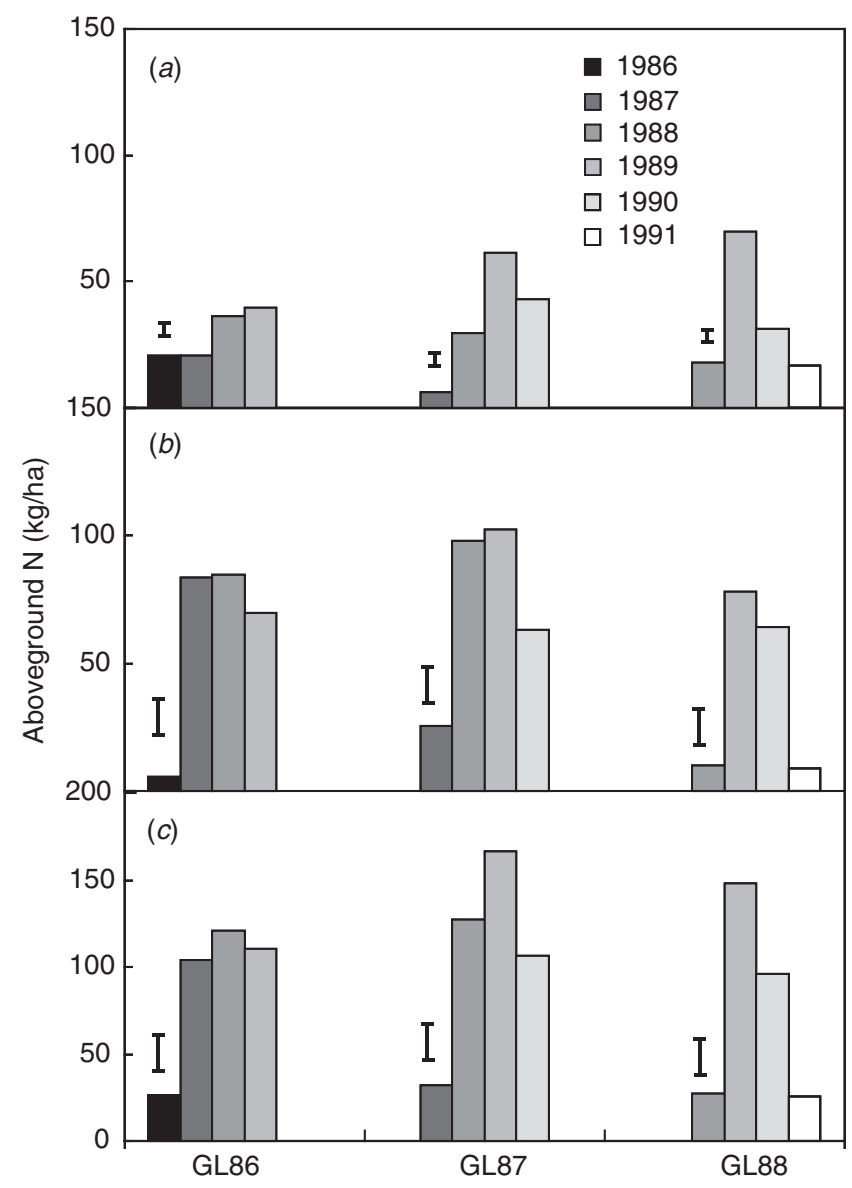

Fig. 5. Annual aboveground $\mathrm{N}(\mathrm{kg} / \mathrm{ha})$ for $(a)$ grass, $(b)$ legume, and $(c)$ total grass and legume pasture components during 3 mixed pastures each of 45 months duration. GL86, GL87 and GL88 are shown separately.

stored water supply was $<134 \mathrm{~mm}$; water storages for most assay crops were $67-110 \mathrm{~mm}$, equivalent wet soil depth of only $0.3-0.45 \mathrm{~m}$.

\section{Root disease}

Generally, ley pastures did not reduce the incidence of common root rot of wheat. In fact, there appeared to be

Table 3. Soil nitrate-N (kg N/ha.1.2 $\mathrm{m}$ depth) in May before wheat sowing following mixed grass and legume pastures sown in 1986 (GL86), 1987 (GL87) and 1988 (GL88) and wheat-wheat rotation

For wheat-wheat rotation, fertiliser $\mathrm{N}$ was applied after soil sampling for nitrate $\mathrm{N}$

\begin{tabular}{lcccccc}
\hline Crop year & GL86-wheat & GL87-wheat & GL88-wheat & $\begin{array}{c}\text { Wheat-wheat } \\
0 \mathrm{~kg} \mathrm{~N} / \mathrm{ha}\end{array}$ & $\begin{array}{c}\text { Wheat-wheat } \\
75 \mathrm{~kg} \mathrm{~N} / \mathrm{ha}\end{array}$ & $\begin{array}{c}\text { 1.s.d. } \\
(P=0.05)\end{array}$ \\
\hline 1990 & 118.8 & Pasture & Pasture & 37.9 & 62.6 & 17.6 \\
1992 & 167.2 & 282.2 & 105.0 & 88.7 & 179.3 & 46.6 \\
1993 & 163.4 & 270.1 & 116.7 & 35.2 & 140.2 & 55.4 \\
1994 & 107.2 & 175.6 & 65.7 & 46.6 & 143.4 & 60.3 \\
1995 & 97.3 & 205.0 & 86.9 & 62.5 & 168.4 & 73.1 \\
\hline
\end{tabular}




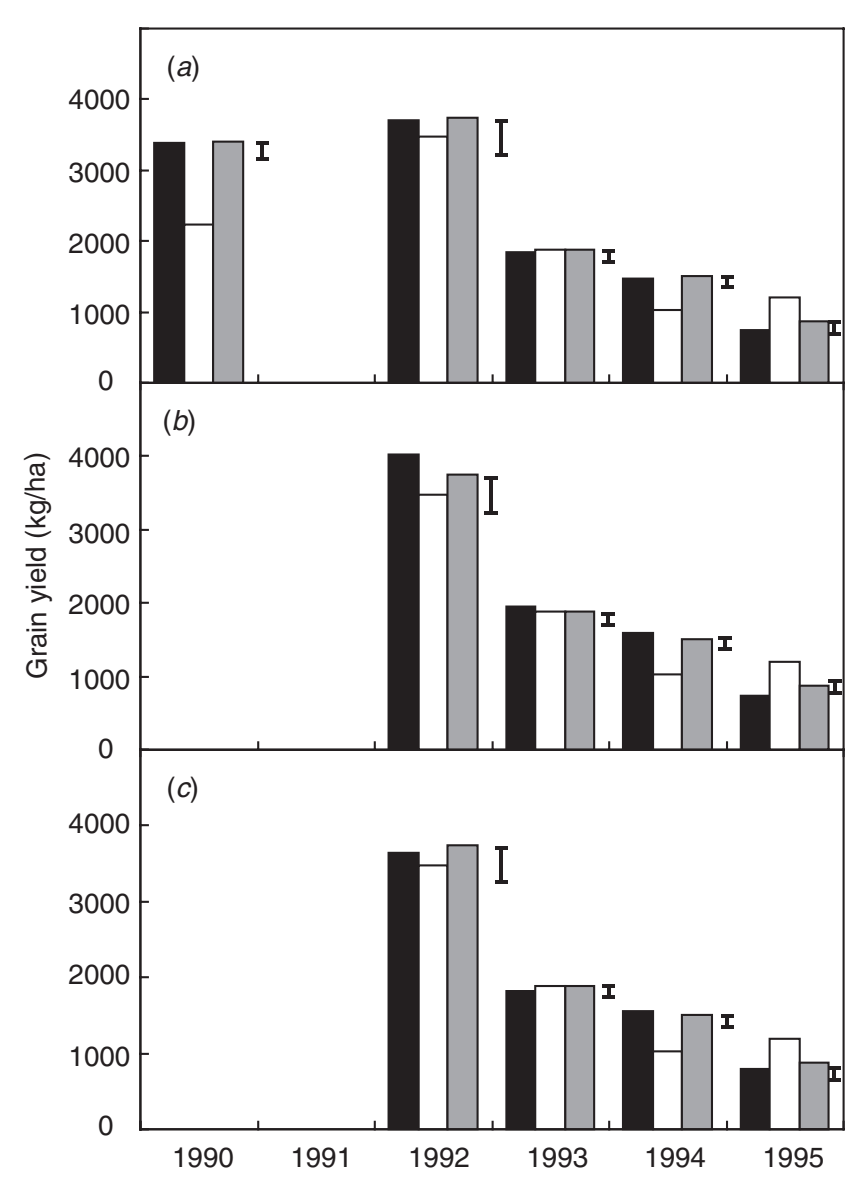

Fig. 6. Grain yield of wheat crops after (a) GL86, (b) GL87, and (c) GL88 were terminated (black bars) and continuous wheat with $0 \mathrm{~kg} \mathrm{~N} / \mathrm{ha}$ (white bars) or $75 \mathrm{~kg} \mathrm{~N} / \mathrm{ha}$ (grey bars) applied. Insufficient rainfall in 1991 prevented wheat sowing after GL86 and GL87.

higher incidence and severity of common root rot of wheat in post-pasture treatments than continuous wheat treatment (Table 5). Incidence of crown rot of wheat remained low in all treatments during this study.

\section{Discussion}

Dry matter production in grass and legume pastures

Pasture composition and production measured by the "cut and carry' removal method (all data presented) were generally

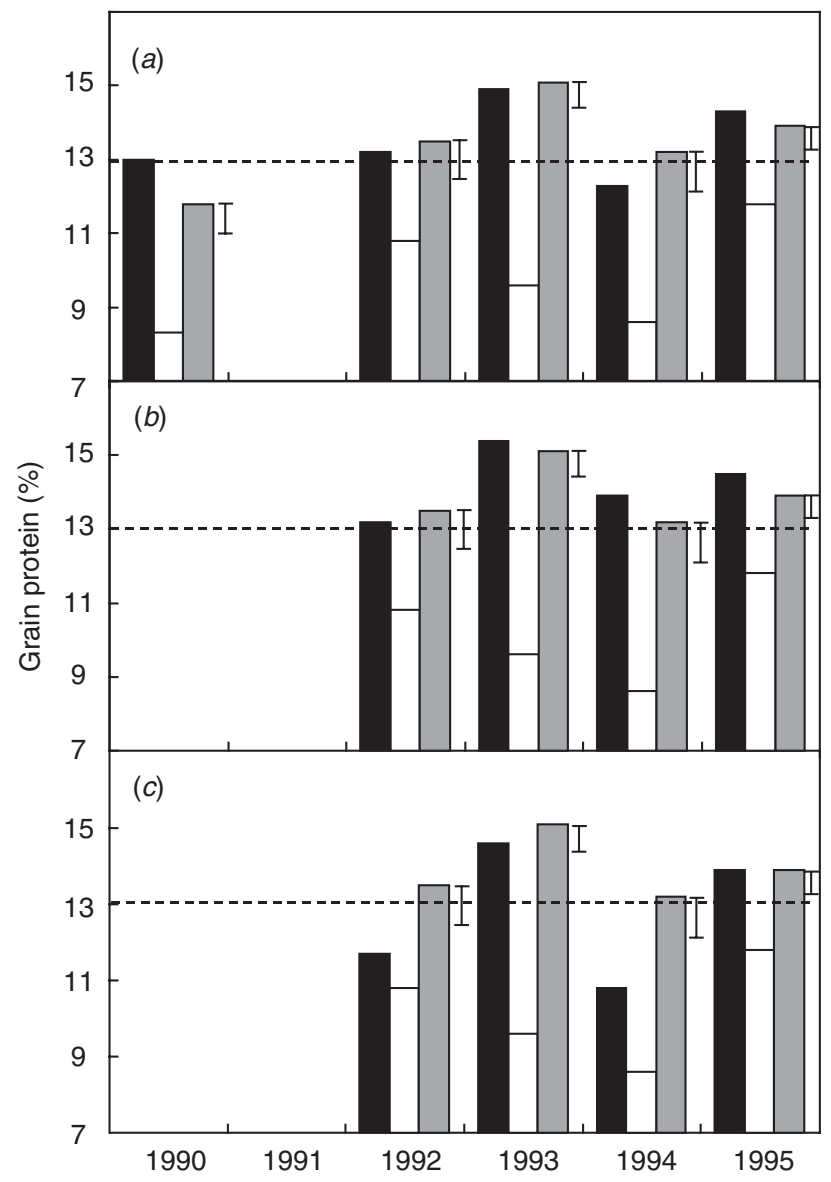

Fig. 7. Grain protein concentrations of wheat after (a) GL86, (b) GL87, and (c) GL88 were terminated (black bars) and continuous wheat with $0 \mathrm{~kg} \mathrm{~N} / \mathrm{ha}$ (white bars) or $75 \mathrm{~kg} \mathrm{~N} / \mathrm{ha}$ (grey bars) applied. Insufficient rainfall in 1991 prevented wheat sowing after GL86 and GL87.

similar to those of the adjacent pastures that were grazed (data not shown). Two exceptions to the close agreement in pasture production between methods of pasture removal were observed; grass production for the grazed was double that of the cut and removed in the January-March periods of 1988 and 1989. As observed by Weston et al. (2002) and Dalal et al. (2004a) for pure swards of medic and lucerne pastures, compared in this experiment and reported

Table 4. Wheat grain and stubble $\mathrm{N}$ yield ( $\mathrm{kg} \mathrm{N} / \mathrm{ha}$ ) following mixed grass and legume pastures sown in 1986 (GL86), 1987 (GL87) and 1988 (GL88) and wheat-wheat rotation

\begin{tabular}{lccccrr}
\hline Crop year & GL86-wheat & GL87-wheat & GL88-wheat & $\begin{array}{c}\text { Wheat-wheat } \\
0 \mathrm{~kg} \mathrm{~N} / \mathrm{ha}\end{array}$ & $\begin{array}{c}\text { Wheat-wheat } \\
75 \mathrm{~kg} \mathrm{~N} / \mathrm{ha}\end{array}$ & $\begin{array}{c}\text { 1.s.d. } \\
(P=0.05)\end{array}$ \\
\hline 1990 & 107.5 & Pasture & Pasture & 41.9 & 97.3 & 8.9 \\
1992 & 108.1 & 115.8 & 88.0 & 81.6 & 112.1 & 17.8 \\
1993 & 63.9 & 69.9 & 63.2 & 36.5 & 69.3 & 5.9 \\
1994 & 46.4 & 61.6 & 43.6 & 20.6 & 56.4 & 9.0 \\
1995 & 27.5 & 29.8 & 27.5 & 31.3 & 35.2 & 5.9 \\
\hline
\end{tabular}




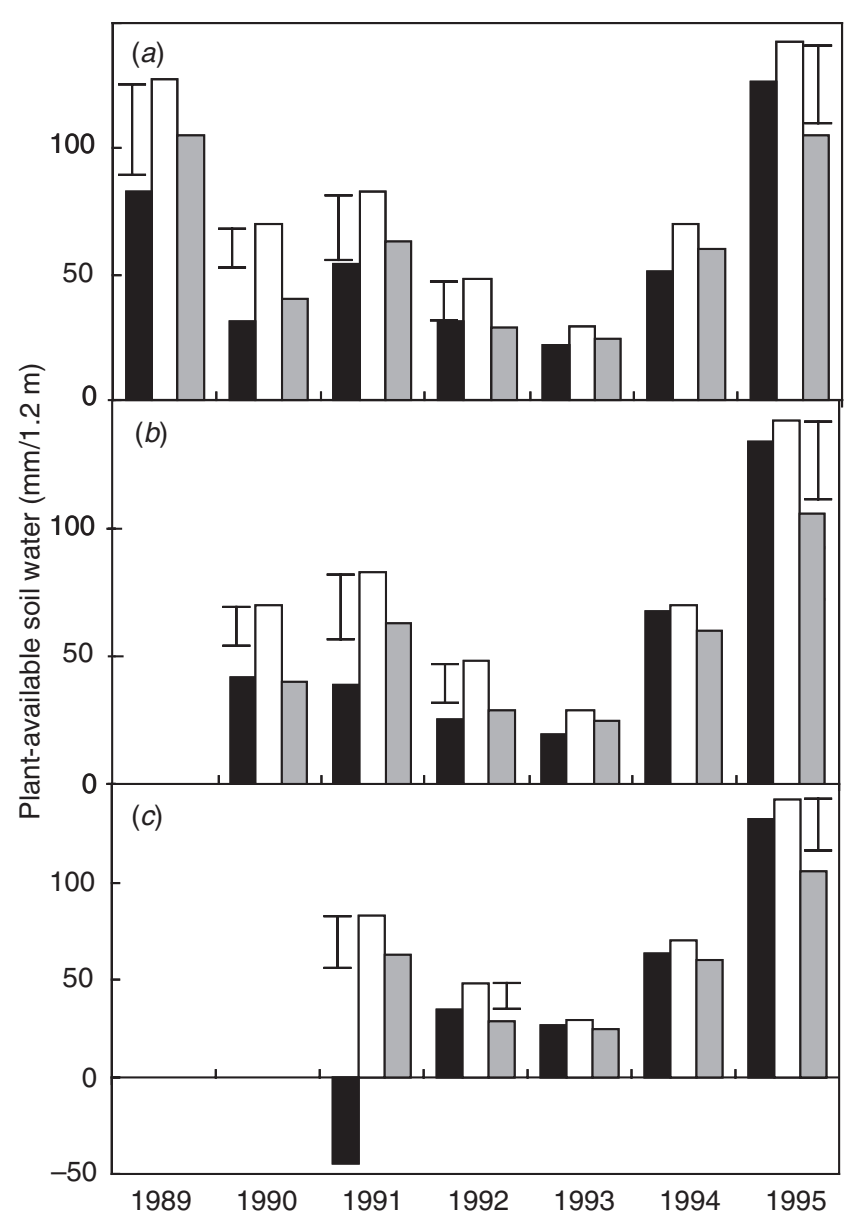

Fig. 8. Plant available soil water $(\mathrm{mm} / 1.2 \mathrm{~m}$ soil) in November during the assay cropping period after (a) GL86, (b) GL87, and (c) GL88 were terminated (black bars) and continuous wheat with $0 \mathrm{~kg} \mathrm{~N} / \mathrm{ha}$ (white bars) or $75 \mathrm{~kg} \mathrm{~N} / \mathrm{ha}$ (grey bars) applied.

previously, no similar increases in performance of legume components owing to grazing were observed. Increased grass production in grazed pastures was to the result of increased nutrient recycling from dung and urine during these 2 wet summer periods when falls of 227 and $165 \mathrm{~mm}$ rainfall were received over 21 and 25 days, respectively.

Incident rainfall appeared to be the dominant factor controlling pasture growth in this experiment. Despite of the very different populations of legume plants that established

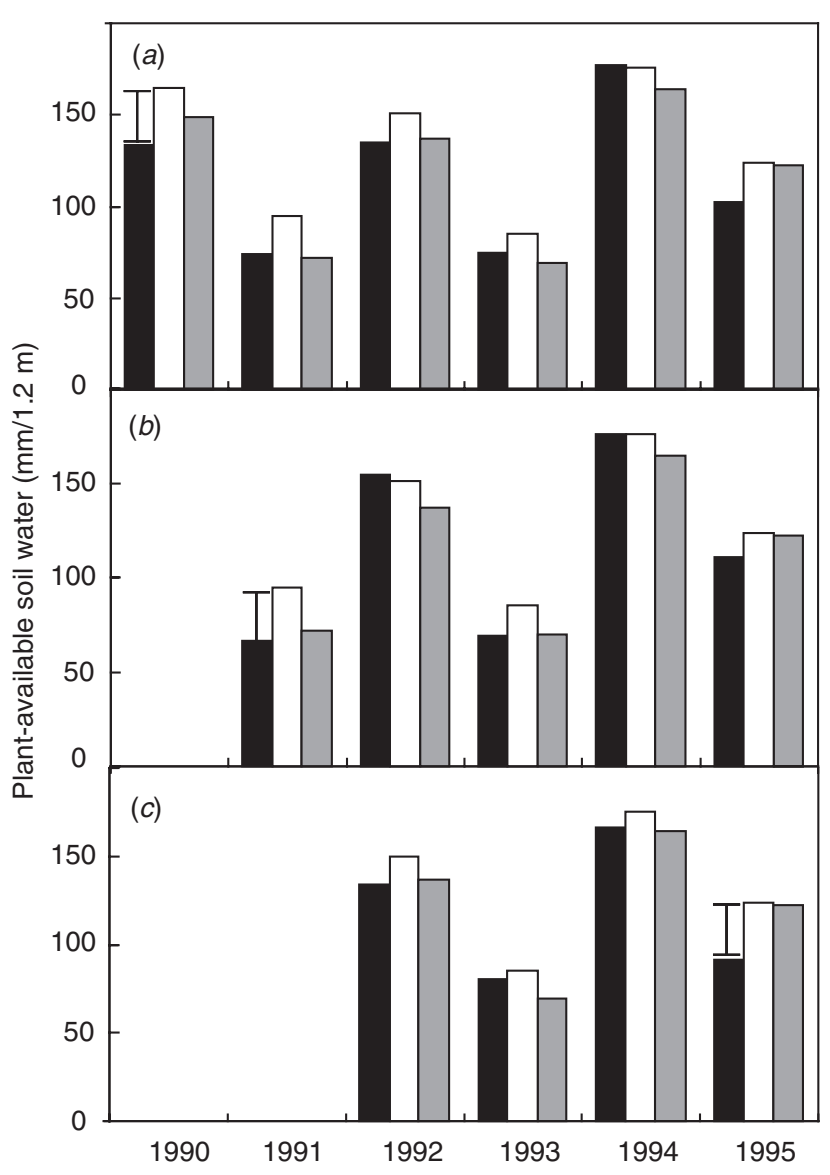

Fig. 9. Plant available soil water $(\mathrm{mm} / 1.2 \mathrm{~m}$ soil) in May prior to sowing wheat crops during the assay cropping period after (a) GL86, (b) GL87, and (c) GL88 were terminated (black bars) and continuous wheat with $0 \mathrm{~kg} \mathrm{~N} / \mathrm{ha}$ (white bars) or $75 \mathrm{~kg} \mathrm{~N} / \mathrm{ha}$ (grey bars) applied.

in the 3 pastures, there was close association between incident rainfall and legume production suggesting that incident rainfall rather than plant numbers had the greater influence on legume production. Grasses responded even more to incident rainfall $(0.52 \pm 0.07 \mathrm{t} / \mathrm{ha} .100 \mathrm{~mm}$ rainfall $)$ than legumes $(0.44 \pm 0.02 \mathrm{t} / \mathrm{ha} .100 \mathrm{~mm})$ in the 3 pastures; weeds were poor competitors with grasses and legumes in all the pastures (Table 1).

Rainfall during most of the experimental period (1986-95) was below average and pasture production

Table 5. Incidence and severity of common root rot in wheat crop following mixed grass and legume pastures sown in 1986 (GL86), 1987 (GL87) and 1988 (GL88) and wheat-wheat rotation at anthesis

\begin{tabular}{lcccccccccc}
\hline $\begin{array}{l}\text { Crop } \\
\text { year }\end{array}$ & $\begin{array}{c}\text { GL86- } \\
\text { wheat }\end{array}$ & $\begin{array}{c}\text { GL87- } \\
\text { wheat }\end{array}$ & $\begin{array}{c}\text { GL88- } \\
\text { wheat }\end{array}$ & $\begin{array}{c}\text { Wheat- } \\
\text { wheat }\end{array}$ & $\begin{array}{c}\text { l.s.d. } \\
(P=0.05)\end{array}$ & $\begin{array}{c}\text { GL86- } \\
\text { wheat }\end{array}$ & $\begin{array}{c}\text { GL87- } \\
\text { wheat }\end{array}$ & $\begin{array}{c}\text { GL88- } \\
\text { wheat }\end{array}$ & $\begin{array}{c}\text { Wheat- } \\
\text { wheat }\end{array}$ & $\begin{array}{c}\text { 1.s.d. } \\
(P=0.05)\end{array}$ \\
\hline 1992 & 34.4 & 36.8 & 31.1 & 23.1 & n.s. & 17.9 & 22.9 & 18.3 & 13.5 & n.s. \\
1993 & 91.7 & 89.5 & 86.3 & 80.8 & n.s. & 72.1 & 64.1 & 58.2 & 61.8 & 13.5 \\
1994 & 82.5 & 83.3 & 64.1 & 41.1 & 15.5 & 43.5 & 32.8 & 23.9 & 11.7 & 11.5 \\
\hline
\end{tabular}


estimated from rainfall data of subsequent years for similar mixes of grasses and legumes ranged from 15.8-21.6 t/ha. Nevertheless it would seem that under these moderate to low rainfall years, mixed grass and legume pasture production (0.93-1.07 t/ha. $100 \mathrm{~mm}$ rainfall) was similar to pure lucerne swards grown during the same dry decade and reported by Dalal et al. (2004a) to be $0.97 \mathrm{t} / \mathrm{ha}$ per $100 \mathrm{~mm}$ of growing season rainfall.

Grasses competed well in all 3 pastures, restricting legume production, mainly lucerne, to about one-third to one-half (3.7-4.8 kg/ha.mm rainfall) that of comparable pure lucerne swards $(9.7 \mathrm{~kg} / \mathrm{ha} . \mathrm{mm})$ grown at this site (Dalal et al. 2004a). Even in the GL87 pasture, which was dominated by lucerne plants at establishment, grass plants, mostly Rhodes grass, increased in number by the second year to contribute substantially to overall DM production (52\%). Lucerne displayed equally competitive qualities in this mix of pasture species. Even in the Rhodes grass dominant GL88 pasture, 5-8 plants $/ \mathrm{m}^{2}$ of lucerne were sustained for the duration of pasture, contributing substantially to DM production (35\%).

\section{Aboveground $N$ in grasses and legumes}

Similarity in aboveground $\mathrm{N}$ yield of legume pasture components, mainly lucerne, was consistent with the populations of legume plants in these pasture mixes. Lowest $\mathrm{N}$ yield of legumes occurred in the grass dominant GL88. However, the considerable variation in legume populations among pastures would have suggested greater variation in aboveground $\mathrm{N}$ yield than the $25 \%$ difference between grass dominant GL88 (5-8 lucerne plants $/ \mathrm{m}^{2}$ ) and legume dominant GL87 ( $>15$ lucerne plants $/ \mathrm{m}^{2}$ ). Nevertheless, from the viewpoint of forage production, the lucerne component of these mixed pastures imparted substantial benefit to aboveground $\mathrm{N}$ available for yield as forage even with a low to moderate population of lucerne plants (5-8 plants $\left./ \mathrm{m}^{2}\right)$.

Aboveground legume $\mathrm{N}$ in each mixed pasture, mainly lucerne, was $<50 \%(0.11-0.13 \mathrm{~kg} / \mathrm{ha} . \mathrm{mm})$ of that previously reported (Dalal et al. 2004a) for comparable pure lucerne swards $(0.26 \mathrm{~kg} / \mathrm{ha} . \mathrm{mm})$ grown at the site. Similar internal legume $\mathrm{N}$ concentrations $(27-29 \mathrm{~kg} \mathrm{~N} / \mathrm{tDM})$ when mixed with grasses as reported by Dalal et al. (2004a) for pure lucerne swards at this site could reflect its capacity to supplement internal plant $\mathrm{N}$ by $\mathrm{N}_{2}$ fixation.

\section{Soil nitrate nitrogen and wheat grain and stubble $N$ yield}

Increases in soil organic $\mathrm{C}$ and $\mathrm{N}$ under these pastures has already been reported by Dalal et al. (1995) and Hossain et al. $(1996 a)$. After the termination of the pasture, and following the summer fallow, organic nitrogen was mineralised to produce higher amounts of nitrate $\mathrm{N}$ than continuous wheat for at least 4 years following GL86 and GL87, and only 1 year following GL88. This was primarily because the legume component, mainly lucerne, was higher in GL86 and GL87 pastures than in GL88 pasture.

\section{Wheat yield and protein}

Seasonal effects on pasture production and, thus, on response of subsequent cereal crops were revealed but not overcome by sowing each mixed pasture of 45 -months duration in 3 successive years, commencing in 1986. Overlapping periods of pasture meant that the effects of moderately good seasons for pasture production in 1988 and 1989 had influence across all 3 pastures.

Low rainfall years of assay cropping after termination of pastures had greater impact on the application of these results for subsequent crop production than did rainfall during pasture growth. On termination of each pasture commencing in 1989, subsequent wheat cropping was interrupted by a period of intensive drought commencing in 1991 (no cropping) and persisting until the end of this assay in 1995 . Hence, the cropping assay after each pasture provided only partial assessment of each pasture's impact on subsequent cereal cropping. Continuance of the assay period for several years longer than was planned would have provided a measure of the impact of high levels of accumulated mineral $\mathrm{N}$ in the soil following pastures. Also, any subtle differences among pastures may have gone unnoticed because of inadequate rainfall to support good production of most assay wheat crops.

Reduced water supplies, reported by Dalal et al. (2004a, $2004 b$ ) after pure swards of lucerne, were also evident after these pastures. Nevertheless, water deficits that were evident at termination of 2 pastures were satisfactorily recharged after a 6-month fallow in 1989 and 1990 after GL86 and 1990 for GL87, thus, enabling wheat cropping to be sustained for 1989 and 1990. Intensive drought commencing in 1991 prevented soil water recharge or even sowing of wheat crop that year, thus, interrupting assay of the GL87 pasture and prolonging the recharge period.

Because of insufficient water supply to wheat crops in most of the assay period, neither soil nitrate $\mathrm{N}$ (Table 3) nor plant available water content at sowing (Fig. 9) were significantly related to grain yield or protein. However, as shown by Dalal et al. (1997), the ratio of plant available soil water $(\mathrm{mm})$ and soil nitrate $\mathrm{N}(\mathrm{kg} / \mathrm{ha})$, in $0-1.2 \mathrm{~m}$ depth, were significantly related to wheat grain protein $\left(R^{2}=0.86\right.$, $P<0.01$ ), thus, demonstrating the strong interaction between water and $\mathrm{N}$ supply. Therefore, for assessing $\mathrm{N}$ benefits from pasture, impact of both water supply and mineralised $\mathrm{N}$, especially on cereal crop assay, must be considered. This was also evident in both incidence and severity of common root rot in wheat crops. No benefits of pasture-wheat rotation were evident due to limited plant available water in these rotations, as reported previously for lucerne-wheat rotation (Dalal et al. 2004a).

Despite of the shortcomings of the assay method, the abilities of these pastures to improve $\mathrm{N}$ supplies to subsequent wheat crops were evident, but largely in grain protein concentration and not in increased grain yields. 
Estimation of $\mathrm{N}$ supply following pasture on subsequent wheat crops during the assay period was equivalent to that of $75 \mathrm{~kg} / \mathrm{ha}$ of fertiliser $\mathrm{N}$ applied annually to each wheat crop. As previously discussed by Dalal et al. (2004a), post-pasture impact on $\mathrm{N}$ supply to subsequent cereals is more reliably reported in terms of value of applied nutrient saved rather than on impact on crop returns. For many cereal grains, crop returns are affected by quality or classification of grain as well as on yield. Because of the changing current values of grains of varying classification, impact of these mixed pastures on crop returns could vary substantially from year to year.

\section{Conclusion}

Mixed grass and legume pasture of 45 months duration provides an option for northern grain growers to restore $\mathrm{N}$ fertility on older cereal cropping lands. Responses of dry matter yields of these pastures to incident rainfall of $0.93-1.07 \mathrm{t} / \mathrm{ha}$ per $100 \mathrm{~mm}$ were similar to those for pure swards of lucerne grown at the same site. Nevertheless, the legume components of these pastures do contribute to overall pasture production $(>35 \%)$ even where grass-dominates pasture at establishment, providing opportunity to benefit soil $\mathrm{N}$ supply as well as provide protein enhanced feed to livestock.

Post-pasture benefits appear to be derived primarily through increased cereal grain protein concentrations. Grain yield increases after pasture may occur when suitable wheat growing conditions occur. However, during a period of intensive drought that dominated the assay-cropping phase, inadequate supplies of soil water prevented full expression of any fertility enhancing effects of pasture. Nevertheless, even when soil's water supplies are not recharged, substantial increases in grain protein concentrations provide evidence that $\mathrm{N}$ supplies to subsequent wheat crops are improved. In a subsequent paper we report post-pasture effects on a variety of measures reflecting soil $\mathrm{N}$ fertility.

\section{Acknowledgments}

We thank $\mathrm{Mr}$ Peter Bock and $\mathrm{Mr}$ Tim Reid for providing land for the Warra Experiment, the Queensland Wheat Research Committee and Grains Research and Development Corporation for the financial support, and Dr Graham Wildermuth for data on common root rot of wheat in the trial.

\section{References}

Armstrong RD, Kuskopf BJ, Millar G, Whitbread AM, Standley J (1999a) Changes in soil chemical and physical properties following legumes and opportunity cropping on a cracking clay soil. Australian Journal of Experimental Agriculture 39, 445-456. doi: 10.1071/EA99014

Armstrong RD, McCosker K, Johnson SB, Walsh KB, Millar G, Kuskopf B, Standley J, Probert ME (1999b) Legume and opportunity cropping systems in central Queensland. 1. Legume growth, nitrogen fixation, and water use. Australian Journal of Agricultural Research 50, 909-924. doi: 10.1071/AR98100
Best EK (1976) An automated method for the determination of nitratenitrogen in soil extracts. Queensland Journal of Agricultural and Animal Sciences 33, 161-166.

Crooke WM, Simpson WE (1971) Determination of ammonium in Kjeldahl digests of crops by an automated procedure. Journal of the Science of Food and Agriculture 22, 9-10.

Dalal RC, Mayer RJ (1986a) Long-term trends in fertility of soils under continuous cultivation and cereal cropping in southern Queensland. I. Overall changes in soil properties and trends in winter cereal yields. Australian Journal of Soil Research 24, 265-279. doi: 10.1071/SR9860265

Dalal RC, Mayer RJ (1986b) Long-term trends in fertility of soils under continuous cultivation and cereal cropping in southern Queensland. II. Total organic carbon and its rate of loss from the soil profile. Australian Journal of Soil Research 24, 281-292. doi: 10.1071/SR9860281

Dalal RC, Mayer RJ (1986c) Long-term trends in fertility of soils under continuous cultivation and cereal cropping in southern Queensland. $\mathrm{V}$. Rate of loss of total nitrogen from the soil profile and changes in carbon-nitrogen ratios. Australian Journal of Soil Research 24, 493-504. doi: 10.1071/SR9860493

Dalal RC, Strong WM, Weston EJ, Gaffney J (1991) Sustaining multiple production systems. 2. Soil fertility decline and restoration of cropping lands in sub-tropical Queensland. Tropical Grasslands 25, 173-180.

Dalal RC, Strong WM, Weston EJ, Cooper JE, Lehane KJ, King AJ, Chicken CJ (1995) Sustaining productivity of a Vertosol at Warra, Queensland, with fertiliser, no-tillage, or legumes. 1. Organic matter status. Australian Journal of Experimental Agriculture 35, 903-913. doi: 10.1071/EA9950903

Dalal RC, Strong WM, Weston EJ, Cooper JE, Thomas GA (1997) Prediction of grain protein in wheat and barley in a subtropical environment from available water and nitrogen in Vertosols at sowing. Australian Journal of Experimental Agriculture 37, 351-357. doi: 10.1071/EA96126

Dalal RC, Weston EJ, Strong WM, Lehane KJ, Cooper JE, King AJ, Holmes CJ (2004a) Sustaining productivity of a Vertosol at Warra, Queensland, with fertiliser, no-tillage and legumes. 7. Yield, nitrogen and disease-break benefits from lucerne in a two-year lucernewheat rotation. Australian Journal of Experimental Agriculture 44, 607-616. doi: 10.1071/EA02115

Dalal RC, Weston EJ, Strong WM, Lehane KJ, Cooper JE, King AJ, Holmes CJ (2004b) Sustaining productivity of a Vertosol at Warra, Queensland, with fertiliser, no-tillage and legumes. 8. Effect of duration of lucerne ley on soil nitrogen and water, wheat yield and protein. Australian Journal of Experimental Agriculture 44, 1013-1024. doi: 10.1071/EA03166

Hallsworth EG, Gibbons FR, Lemerle TH (1954) The nutrient status and cultivation practices of soils of the north-west wheat belt of New South Wales. Australian Journal of Agricultural Research 5, 422-447. doi: 10.1071/AR9540422

Holford ICR (1980) Effects of duration of grazed lucerne on longterm yields and nitrogen uptake of subsequent wheat. Australian Journal of Agricultural Research 31, 239-250. doi: 10.1071/ AR9800239

Holford ICR, Crocker GJ (1997) A comparison of chickpeas and pasture legumes for sustaining yields and nitrogen status of subsequent wheat. Australian Journal of Agricultural Research 48, 305-315. doi: 10.1071/A96072

Holford ICR, Doyle AD (1992) Yield responses and nitrogen fertilizer requirements of wheat in relation to soil nitrate levels at various depths. Australian Journal of Soil Research 30, 683-694. doi: $10.1071 /$ SR9920683 
Holford ICR, Schweitzer BE, Crocker GJ (1998) Comparative effects of subterranean clover, medic, lucerne, and chickpea in wheat rotations, on nitrogen, organic carbon, and moisture in two contrasting soils. Australian Journal of Soil Research 36, 57-72. doi: 10.1071/S97036

Hossain SA, Dalal RC, Waring SA, Strong WM, Weston EJ (1996a) Comparison of legume-based cropping systems at Warra, Queensland. I. Soil nitrogen and organic carbon accretion and potentially mineralisable nitrogen. Australian Journal of Soil Research 34, 273-287. doi: 10.1071/SR9960273

Hossain SA, Strong WM, Waring SA, Dalal RC, Weston EJ (1996b) Comparison of legume-based cropping systems at Warra, Queensland. II. Mineral nitrogen accumulation and availability to subsequent wheat crop. Australian Journal of Soil Research 34, 289-297. doi: 10.1071/SR9960289

Littler JW (1984) Effect of pasture on subsequent wheat crops on a black earth soil of the Darling Downs. I. The overall experiment. Queensland Journal of Agriculture and Animal Sciences 41, 1-12.

Peoples MB, Baldock JA (2001) Nitrogen dynamics of pastures: nitrogen fixation inputs, the impact of legumes on soil nitrogen fertility, and the contributions of fixed nitrogen to Australian farming systems. Australian Journal of Experimental Agriculture 41, 327-346. doi: 10.1071/EA99139

Strong WM, Dalal RC, Weston EJ, Cooper JE, Lehane KJ, King AJ, Chicken CJ (1996a) Sustaining productivity of a Vertosol at Warra, Queensland, with fertiliser, no-tillage and legumes. 2. Long-term fertiliser needs to enhance wheat yields and grain protein. Australian Journal of Experimental Agriculture 36, 665-674. doi: 10.1071/EA9960665
Strong WM, Dalal RC, Cahill MJ, Weston EJ, Cooper JE, Lehane KJ, King AJ, Chicken CJ (1996b) Sustaining productivity of a Vertosol at Warra, Queensland, with fertiliser, no-tillage or legumes. 3. Effect of nitrate accumulated in fertilised soil on crop response and profitability. Australian Journal of Experimental Agriculture 36, 675-682. doi: 10.1071/EA9960675

Weston EJ, Dalal RC, Strong WM, Lehane KJ, Cooper JE, King AJ, Holmes CJ (2002) Sustaining productivity of a Vertosol at Warra, Queensland, with fertiliser, no-tillage and legumes. 6. Production and nitrogen benefits from annual medic in rotation with wheat. Australian Journal of Experimental Agriculture 42, 961-969. doi: 10.1071/EA01083

Whitehouse MJ, Littler JW (1984) Effect of pasture on subsequent wheat crops on a black earth soil of the Darling Downs. II. Organic $\mathrm{C}$, nitrogen and $\mathrm{pH}$ changes. Queensland Journal of Agriculture and Animal Sciences 41, 13-20.

Wildermuth GB, Tinline AD, McNamara RB (1992) Assessment of yield loss caused by common root rot in wheat cultivars in Queensland. Australian Journal of Agricultural Research 43, 43-58. doi: 10.1071/AR9920043

Received 17 January 2005, accepted 11 August 2005 